\title{
Criminologie
}

\section{News that Counts: Newspaper Images of Crime and Victimization Statistics}

\author{
Vincent F. Sacco
}

Volume 33, numéro 1, printemps 2000

La victimologie : quelques enjeux

URI : https://id.erudit.org/iderudit/004744ar

DOI : https://doi.org/10.7202/004744ar

Aller au sommaire du numéro

\section{Éditeur(s)}

Les Presses de l'Université de Montréal

ISSN

0316-0041 (imprimé)

1492-1367 (numérique)

Découvrir la revue

Citer cet article

Sacco, V. F. (2000). News that Counts: Newspaper Images of Crime and Victimization Statistics. Criminologie, 33(1), 203-223.

https://doi.org/10.7202/004744ar
Résumé de l'article

L'étude des images médiatiques du crime et de la victimisation tend à ne tenir compte que des comptes rendus d'actes criminels. L'utilisation des statistiques criminelles et de victimisation, cependant, constitue un thème important quoique rarement abordé dans le cadre de la couverture médiatique d'évènements à caractère criminel. Certains sociologues constructivistes, comme Joel Best, ont affirmé que ces statistiques interviennent de facon déterminante, en tant qu'instruments de rhétorique non négligeables, dans les processus sociaux de construction et de maintien de problématiques criminelles et sociales. De telles statistiques servent à appuyer (justifier/légitimer) les affirmations concernant l'étendue (l'importance) et la portée de nouveaux problèmes, et, par là-même, la nécessité d'une action sociale sans délai.

Lors de la phase initiale du processus, ces affirmations peuvent être émises par ceux qui, tout en étant dépourvus de statut officiel, sont sans doute les seuls à s'intéresser au problème naissant. L'utilité de la légitimité conférée aux problèmes sociaux par les statistiques n'est cependant pas exclusivement pertinente aux premiers stades du processus de construction. Pour demeurer à l'ordre du jour, les problèmes sociaux nécessitent qu'on les entretienne et la diffusion régulière d'informations statistiques censées documenter les changements de portée ou d'étendue d'un problème est essentielle à cet entretien. Le plus souvent, ce sont les organismes gouvernementaux qui se chargent de rassembler et de disséminer les informations relatives à des problèmes déjà identifiés. En général, les affirmations fondées sur les statistiques concernant des problématiques criminelles ou sociales parviennent à l'attention du grand public par le truchement des mass media, tout particulièrement les médias d'information. Le présent article analyse les nouvelles portant sur des statistiques criminelles qui sont parues dans la presse canadienne anglophone au cours des années 1993 et 1994. L'examen d'une banque de données informatisée, ainsi que celui plus attentif d'articles parus lors de périodes intensives d'affirmations fondées sur les statistiques, ont tous domaine del la constitutictur.

L'analyse est centrée autour de deux questions principales. La première a trait aux moyens par lesquels les ffirmations fondées sur les statistiques et relatives au crime et à la victimisation s'introduisent dans le circuit ediratie. Pour dire les choses autrement, quelles sont les « affirmations statistiques » relatives au crime qui

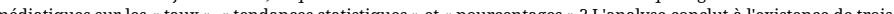

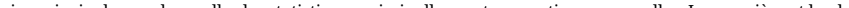
vourante consiste en la présentation de donnés à l'occasion de conférences de presse, de la publication de 作 cour

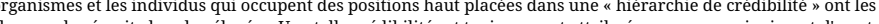
fficiel. Une deuxième facon de s'accrocher au train médiatique se caractérise par des tentatives de discrédit out accusations d'erreurs statistiques. Dans ces cas, de "nouvelles " statistiques remettent en question ce que les" précédentes avaient encouragé les audiences à croire. Une troisième voie par laquelle les statistiques criminelles et de victimisation entrent dans le circuit médiatique se rapporte à l'usage qui en est fait comme moyen d'information complémentaire à un sujet plus substantiel.

La deuxième grande question autour de laquelle est centré cet article traite de la façon par laquelle l'information statistique est présentée de manière à ce qu'elles soient en conformité avec les valeurs véhiculées par les médias. statistique est présentée de manière à ce qu'elles soient en conformité avec les valeurs véhiculées par les médias. Qui plus est, un effort journalistique considérable est fourni dans le but " de colorer " les histoires comportant des statistiques, en ayant recours à l'humour ou au drame et en faisant jouer l'intérêt public. De même, l'accent est-il régulièrement mis sur l'importance des statistiques présentées, ainsi que sur le caractère objectif de leur compte régulièren.

La couverture médiatique des évènements criminels se voit souvent adresser le reproche que les journalistes préfèrent clairement les mauvaises nouvelles. Notre analyse révèle cependant que les journalistes pourraient bien être davantage intéressés par les nouvelles faciles que les mauvaises nouvelles. La disponibilité des statistiques officielles (qui, dans cet échantillon du moins, décrivaient souvent des tendances stables ou en déclin) ainsi que l'apport des sociologues des écoles de pensée libérales, faisant office de contrepoids aux voix plus conservatrices de organismes de réglementation et des associations de victimes, indiquent que les images statistiques véhiculées par
les médias sont bien souvent plus complexes qu'on ne le suppose.
Tous droits réservés @ C Les Presses de l'Université de Montréal, 2000
Ce document est protégé par la loi sur le droit d'auteur. L’utilisation des services d’Érudit (y compris la reproduction) est assujettie à sa politique d'utilisation que vous pouvez consulter en ligne.

https://apropos.erudit.org/fr/usagers/politique-dutilisation/ 


\title{
News that Counts: Newspaper Images of Crime and Victimization Statistics ${ }^{1}$
}

\author{
Vincent F. Sacco \\ Professor, \\ Department of Sociology \\ Queen's University • Canada \\ saccov@post.queensu.ca
}

RÉSUMÉ - L'étude des images médiatiques du crime et de la victimisation tend à ne tenir compte que des comptes rendus d'actes criminels. L'utilisation des statistiques criminelles et de victimisation, cependant, constitue un thème important quoique rarement abordé dans le cadre de la couverture médiatique d'évènements à caractère criminel. Certains sociologues constructivistes, comme Joel Best, ont affirmé que ces statistiques interviennent de facon déterminante, en tant qu'instruments de rhétorique non négligeables, dans les processus sociaux de construction et de maintien de problématiques criminelles et sociales. De telles statistiques servent à appuyer (justifier/ légitimer) les affirmations concernant l'étendue (l'importance) et la portée de nouveaux problèmes, et, par là-même, la nécessité d'une action sociale sans délai.

Lors de la phase initiale du processus, ces affirmations peuvent être émises par ceux qui, tout en étant dépourvus de statut officiel, sont sans doute les seuls à s'intéresser au problème naissant. L'utilité de la légitimité conférée aux problèmes sociaux par les statistiques n'est cependant pas exclusivement pertinente aux premiers stades du processus de construction. Pour demeurer à l'ordre du jour, les problèmes sociaux nécessitent qu'on les entretienne, et la diffusion régulière d'informations statistiques censées documenter les changements de portée ou d'étendue d'un problème est essentielle à cet entretien. Le plus souvent, ce sont les organismes gouvernementaux qui se chargent de rassembler et de disséminer les informations relatives à des problèmes déjà identifiés. En général, les affirmations fondées sur les statistiques concernant des pro-

1. An earlier version of this paper was presented at the annual meeting of the American Society of Criminology, Washington D.C., 1998 
blématiques criminelles ou sociales parviennent à l'attention du grand public par le truchement des mass media, tout particulièrement les médias d'information.

Le présent article analyse les nouvelles portant sur des statistiques criminelles qui sont parues dans la presse canadienne anglophone au cours des années 1993 et 1994. L'examen d'une banque de données informatisée, ainsi que celui plus attentif d'articles parus lors de périodes intensives d'affirmations fondées sur les statistiques, ont tous deux abouti à la constitution d'un échantillon final de 244 articles, issus des principaux journaux et revues dans le domaine de l'actualité.

L'analyse est centrée autour de deux questions principales. La première a trait aux moyens par lesquels les affirmations fondées sur les statistiques et relatives au crime et à la victimisation s'introduisent dans le circuit médiatique. Pour dire les choses autrement, quelles sont les « affirmations statistiques » relatives au crime qui attirent l'attention des journalistes, et quels sont les thèmes accrocheurs autour desquels gravitent les discussions médiatiques sur les «taux », «tendances statistiques » et « pourcentages »? L'analyse conclut à l'existence de trois voies principales par lesquelles les statistiques criminelles sont converties en nouvelles. La première et la plus courante consiste en la présentation de données à l'occasion de conférences de presse, de la publication de nouvelles recherches ou de la diffusion régulière de données par les organismes gouvernentaux. Parmi ceux qui tentent d'utiliser cette voie, seul un certain nombre s'avère susceptible d'attirer l'attention des médias ; les organismes et les individus qui occupent des positions haut placées dans une « hiérarchie de crédibilité » ont les chances de réussite les plus élevées. Une telle crédibilité est typiquement attribuée aux sources jouissant d'un statut officiel. Une deuxième façon de s'accrocher au train médiatique se caractérise par des tentatives de discrédit ou des accusations d'erreurs statistiques. Dans ces cas, de « nouvelles » statistiques remettent en question ce que les précédentes avaient encouragé les audiences à croire. Une troisième voie par laquelle les statistiques criminelles et de victimisation entrent dans le circuit médiatique se rapporte à l'usage qui en est fait comme moyen d'information complémentaire à un sujet plus substantiel.

La deuxième grande question autour de laquelle est centré cet article traite de la façon par laquelle l'information statistique est présentée de manière à ce qu'elles soient en conformité avec les valeurs véhiculées par les médias. L'analyse donne à croire que les journalistes emploient un certain nombre de stratégies afin d'atteindre cet objectif. Qui plus est, un effort journalistique considérable est fourni dans le but « de colorer » les histoires comportant des statistiques, en ayant recours à l'humour ou au drame et en faisant jouer l'intérêt public. De même, l'accent est-il régulièrement mis sur l'importance des statistiques présentées, ainsi que sur le caractère objectif de leur compte rendu.

La couverture médiatique des évènements criminels se voit souvent adresser le reproche que les journalistes préfèrent clairement les mauvaises nouvelles. Notre analyse révèle cependant que les journalistes pourraient bien être davantage intéressés par les nouvelles faciles que les mauvaises nouvelles. La disponibilité des statistiques officielles (qui, dans cet échantillon du moins, décrivaient souvent des tendances stables ou en déclin) ainsi que l'apport des sociologues des écoles de pensée libérales, faisant office de contrepoids aux voix plus conservatrices des organismes de réglementation et des associations de victimes, indiquent que les images statistiques véhiculées par les médias sont bien souvent plus complexes qu'on ne le suppose. 
ABSTRACT - The study of media images of crime and victimization has tended to focus on the reporting of criminal events. However, the reporting of crime and victimization statistics is an important, if unaddressed theme in crime news coverage. Such statistics, as Joel Best and other social constructionists have argued, perform as important rhetorical devices in the social processes by which crime and (other social) problems are constructed and maintained. Such statistics are used to press claims about the pervasiveness and scope of new problems and therefore about the need for urgent social action.

At the earliest stages, these claims may be issued by those who have no official status but who may be the only ones interested in the emergent issue. The legitimacy which statistics lend to social problems is relevant not only at the initial phases of construction, however. To remain on the public agenda, social problems require maintenance. And the regular diffusion of statistical information which purports to document shifts in the scope or size of the problem is essential to such maintenance. Most often, the role of collecting and disseminating statistical information regarding established problems is assumed by state agencies. In general, statistical claims about crime and other social problems reach the general public via the mass media - most importantly the news media.

This paper examines news reporting about crime statistics which appeared in Canadian English language print media during the calendar years 1993 and 1994. A search of a computerized data base and a more detailed search of news items appearing during more intensive periods of statistical claim-making yielded a final sample of 244 news articles from major newspapers and newsmagazines.

Two broad questions form the focus of the analysis. The first concerns the means by which statistical claims about crime and victimization enter the news flow. Put simply, to whose statistical claims about crime do journalists pay attention and what are the "news hooks" on which media discussions of rates, statistical trends and percentages are hung? The analysis finds that there are principally three routes by which crime statistics become news. The first and most common is the "data release" in the form of press conferences, the release of a new study or the regular release of data by state agencies. Not all of those who seek to make statistical claims of this type are equally likely to attract the attention of the media, and those agencies and individuals who occupy superordinate positions within a hierarchy of credibility are most likely to prove successful in this regard. Such credibility is most typically conveyed via the official status of the source. A second major form of news hook involves efforts at "debunking" or charges of statistical error. In these cases, "new" statistical findings call into question what earlier statistics encouraged audiences to believe. A third route by which crime and victimization statistics enter the news flow relates to the use of statistics as "background" information with respect to some more substantive theme.

The second major question on which the paper is focused involves a consideration of the ways in which statistical news is packaged so as to ensure conformity with dominant news values. The analysis suggests that journalists employ a number of strategies to meet these objectives. Most important, there is considerable journalistic effort to dress stories involving statistics in ways that emphasize humour, drama and public interest. As well, an attempt is routinely made to emphasize the importance of reported statistics and the objective character of the reporting itself. 
A persistent criticism of media reporting of crime is that there is a clear journalistic preference for bad news. This analysis reveals, however, that journalists might be more interested in easy news than in bad news. The availability of official statistics (which in this sample, at least, often described stable or declining trends) and the reliance on liberal social scientists as a counterpoint to the more conservative voices of policing agencies and victims' organizations implies that the statistical images in the media are often more complex than they are assumed to be.

RESUMEN - El estudio periodístico de las imágenes sobre el delito y la victimización se ha centrado tradicionalmente en el reportaje de los eventos delictivos. No obstante, la incorporación de estadísticas sobre delitos y victimización representa un importante a la vez que descuidado aspecto en la cobertura de las noticias sobre el tema. Estas estadísticas, tal como lo han indicado Joel Best y otros constructivistas, cumplen un importante papel retórico en los procesos sociales mediante los cuales se elaboran y mantienen en la escena pública el delito y otros problemas sociales. Dichas estadísticas suelen utilizarse para apoyar las peticiones del público en cuanto a la proliferación y el alcance de nuevos problemas, y por lo tanto sobre la necesidad de una intervención social urgente.

En sus primera etapas, las peticiones pueden provenir de personas que carecen de una condición oficial, pero que parecieran ser los únicos interesados en el nuevo problema. Sin embargo la legitimidad por la cual los datos estadísticos conducen al análisis de los asuntos sociales no es relevante sólo en los inicios del proceso constructivo. Para permanecer como tema de la agenda pública la discusión de los problemas sociales exige el mantenimiento, y la difusión constante de la información estadística. Esto implica documentar las variaciones en cuanto al alcance o a la dimensión del problema. Muy a menudo, la función de recoger y diseminar información de tipo estadìstico en materia de problemas sociales es tarea de agencias oficiales. Regularmente, las peticiones sobre estadísticas en lo que se refiere al delito y otros problemas sociales llegan al público por la vía de los medios de información en especial el medio de las noticias. El presente trabajo examina el reportaje noticioso sobre las estadísticas delictivas aparecidas en medios canadienses impresos en lengua inglesa, durante los años calendarios 1993 y 1994. Una búsqueda en la base de datos computarizada y una búsqueda más detallada de nuevos elementos informativos aparecidos en períodos especialmente críticos de demanda, permitieron obtener una muestra final de 244 artículos de prensa, extraídos de los principales diarios y revistas de noticiosas.

Dos preguntas generales resumen el centro del estudio. La primera se refiere a la manera como se incorporan al flujo de noticias las solicitudes sobre estadísticas del delito y la victimización. Dicho en términos más simples, ¿a cuáles peticiones estadísticas sobre el delito prestan realmente atención los periodistas y cuáles serían los « nuevos ganchos » de los que « cuelgan » las discusiones en los medios de información cuando se trata de porcentajes, tasas y tendencias en este campo?

El estudio indica la existencia de tres vías principales a través de las cuales las estadísticas delictivas llegan a convertirse en noticias. La primera y más frecuente es la « divulgación de datos » mediante conferencias de prensa, la publicación de un nuevo estudio o la publicación corriente de cifras por las agencias oficiales. No todos 
los que plantean solicitudes estadísticas de este tipo están igualmente interesados en atraer la atención de los medios y de aquellas agencias. Los que ocupan posiciones importantes en una jerarquía de credibilidad resultan posiblemente los más exitosos en este sentido y esta credibilidad suele transmitirse por intermedio del status oficial de la fuente.

Una segunda vía importante de « gancho noticioso » comprende la desmistificación o el señalamiento de errores estadísticos. En estos casos, los « nuevos » hallazgos numéricos ponen en duda lo que los datos iniciales permitían creer a la audiencia. Una tercera ruta por la cual las estadísticas sobre el delito y la victimización entran al flujo de noticias tiene que ver con el uso de las estadísticas en términos de información contextual dentro de un tema más sustancial. La segunda cuestión de importancia sobre la que se centra este artículo involucra la consideración de las formas en que se organizan las noticias sobre estadísticas, de manera que la conformidad con los valores contenidos en las noticias dominantes del momento no resulte afectada. El análisis sugiere que los periodistas utilizan diversas estrategias para alcanzar este objetivo. Lo más relevante : existe un esfuerzo considerable por parte de éstos a fin de elaborar historias que contengan estadísticas que puedan enfatizar tanto el humor como el drama y el interés colectivo. Al mismo tiempo, se trata de destacar de manera constante la importancia de las estadísticas, junto al carácter objetivo del reportaje mismo.

Una crítica permanente de los reportajes noticiosos sobre el delito tiene que ver con la clara preferencia de los reporteros hacia las malas noticias. Este análisis indica, sin embargo, que los periodistas podrían estar más interesados en las noticias de carácter fácil que en las malas noticias. La posibilidad de obtener estadísticas oficiales ( las cuales, en el caso de la muestra utilizada describen tendencias estables o decrecientes) unida a la confianza en los científicos sociales liberales como contrapeso frente a las voces más conservadoras de las instituciones policiales y a la asistencia oficial a las víctimas, señala que las imágenes estadísticas en los medios informativos son a menudo más complejas de lo que parecieran ser.

\section{Introduction}

The treatment of crime by the news media has been the focus of a considerable amount of research in recent years (Chibnall, 1977; Erickson et al., $1989 ;$ 1991). While this research has increased our empirical understanding of the images of crimes, offenders and victims presented to news consumers, considerably less is known about the images of crime and victimization statistics which figure so prominently in crime coverage.

However, news about crime statistics may also figure prominently in the shaping of public perceptions of the crime problem. Best (1999) has argued recently that the creation of several victim categories over the last decade has been legitimated by statistical claims about the seriousness and randomness of victimization. Similarly, Howitt (1982) suggests that 
it may be the occasional reporting of victimization statistics rather than the routine reporting of criminal incidents which fuels public anxiety. He maintains, contrary to the assumptions of most researchers, that members of the public do not act as their own statisticians, aggregating lessons about risk from various news stories concerning specific crimes. Instead, they rely on the images of trends and prevalence made available by the experts and by official sources.

Efforts on the part of newsworkers to cover crime in a balanced and comprehensive way makes them reliant on the kinds of statistical information which is intended to contextualize news about specific incidents. Moreover, the release of crime statistics by public and quasi-public agencies is itself a routine kind of crime news story. Yet the uses to which such data is put by journalists, and the conventions which regulate its distribution, have escaped detailed attention.

This paper investigates images of crime and victimization statistics which appear in Canadian print media. Drawing on insights derived from constructionist approaches to the study of social problems, an effort is made to describe the sources, content and methods of presentation of media-reported statistical claims as they appeared in a sample of articles gathered from daily newspapers and mass periodicals.

\section{Statistics as Rhetoric on Social Problems}

A central concern of social constructionist approaches to social problems is that claims-makers use rhetorical devices so as to dramatize the size and scope of problems. In this respect, considerable attention has been paid to the role of social problem statistics. In the contemporary context, at least, statistics are used to press claims about the pervasiveness and scope of new problems and therefore about the need for urgent social action (Goode and Ben-Yehuda, 1994). At the earliest stages, they may be issued by those who have no official status but who may be the only ones interested in the emergent issue. In such circumstances, these "primary claimsmakers" may have the only data relevant to the problem and by default may be viewed as problem experts (Gilbert, 1997).

The legitimacy which statistics lend to social problems is relevant not only at the initial phases of construction, however. To remain on the public agenda, social problems require maintenance, and the regular diffusion of statistical information which purports to document shifts in 
the scope or size of the problem is essential to such maintenance (Nelson, 1984). Most often, the role of collecting and disseminating statistical information regarding established problems is assumed by state agencies.

In general, statistical claims about crime and other social problems reach the general public via the mass media - most notably the news media. This journalistic role of "secondary claims-makers" (Best, 1989a) has two important implications. First, media coverage allows widespread exposure of audiences to claims about the size or other statistical dimensions of social problems. Second, as with other forms of source material, journalists find it necessary to polish and interpret statistical claims in order to ensure conformity of the source material with the requirements of the medium within which they are working (Orcutt and Turner, 1993).

In the context of media reporting, at all stages of problem construction, statistical claims about crime and victimization typically become detached from the methodologies which produce them. In a sense, the numbers take on a life of their own. As a result of media repetition, audience members may know something about the prevalence or rate of growth of a particular problem, but have little idea of the source of the statistical information (Best, 1989b). In time, the numbers simply become part of the public image of the problem. In one sense, numbers related to social problems seem to behave much like rumors, as they are spread among audiences. Not only do they lose methodological detail, but they increasingly come to reflect the biases and preconceptions of those who pass them along. Thus, Jenkins (1994) has written that, although claims by the FBI that in the early 1980 s there were "about four or five thousand" serial murder victims annually in the United States could not stand up to scrutiny, the numbers were available for embellishment by others interested in constructing new victim categories. In this way, four or five thousand victims of serial murder became four or five thousand female or child victims, which in turn became four or five thousand victims of ritual murder.

\section{The Current Research}

The present research attempts to investigate the ways in which such statistical claims are sourced and packaged by newsworkers in the print media. The analysis proceeds through an examination of a large sample 
of news articles which appeared in Canadian English-language newspapers and magazines during the years 1993 and 1994. The choice of these years was strategic since they witnessed major data releases relating to violence against women and national patterns of victimization. It was assumed that the controversy which surrounded these data releases (Fekete, 1994; Doob, 1995), as well as other new stories relating to, for instance, a national proposal to collect race-crime data, would increase the opportunity to observe the ways in which statistical news about crime is constructed and how it in turns constructs the problem of crime.

An initial sample of news items was generated through several keyword searches of the Canadian Business and Current Affairs database (WinSPIRS) for the years in question. All of the articles identified in the database were located and copied from their original sources. In order to complement the database search, a more intensive search of primary materials was undertaken for periods immediately following major episodes of statistical claim-making (such as the release of the Violence against Women Survey findings). The final sample of 244 news articles represented items drawn from a large number of major daily papers in most regions of the country (including The Vancouver Sun, Calgary Herald, Winnipeg Free Press, Toronto Star, Montreal Gazette and Halifax (bronicle-Herald) as well as a smaller number of periodicals (such as Maclean's and Western Report). Finally, in order to develop some understanding of the relationship between source and print materials, a limited examination was undertaken of the press releases from which print coverage derived.

Two broad questions form the focus of this analysis. The first concerns the means by which statistical claims about crime enter the news flow. To whose statistical claims about crime and victimization do journalists attend and how do numbers and rates come to be seen as news? Second, how is news about statistical claims packaged so as to ensure conformity with dominant news values? Each of these issues is addressed in turn.

\section{The Sources of Statistical Claims}

Where do the statistical claims about crime and crime victims presented to readers of Canadian newspapers and magazines originate? While the origins of these sources are diverse, their character is, in many respects, 
relatively uniform. In short, statistical claims about crime tend to emerge out of the pronouncements of agencies which are part of, or closely associated with, the state. These include, most notably, Statistics Canada, and other federal departments such as Justice and Immigration, as well as federal, provincial or municipal policing agencies.

Over the period under study, there was very little evidence that statistical claims which did not carry some aura of state endorsement were given any prominent treatment. Episodes in which primary claimmakers fabricated statistical claims outright and distributed them to a gullible news media were rare - but not non-existent. One of the few items relevant in this respect dealt with a presentation made to Vancouver city's Park Board in support of the erection of a monument honoring murdered women. The central point of the news item was that a researcher who had addressed the Board earlier had said that 80 per cent of murder victims in Vancouver were women, when other data sources such as the Uniform Crime Reports consistently showed that males are more likely to be murdered than females. The article emphasized the nature of the statistical error with respect to homicide victimization, and stated that the figure given to the Board was drawn from a recent television report, and that it was not possible to verify the statistics. News reports which made reference to such questionable sources, however, were the exception rather than the rule.

The dominance of official sources reflects an essential aspect of statistical claim-making. By and large, the crime and victimization problems to which media give routine attention have already been successfully constructed and thus claim-making has more to with problem-maintenance than problem-construction (Nelson, 1984). The official and quasi-official agencies whose mandate it is to monitor crime trends thus become the major source of statistical news. In general, sources which make news easily and routinely accessible are preferred over other news sources (Gans, 1979; Ericson et al., 1989). Since police or other institutional data which can be judged as authoritative, credible and impartial meet newsworkers' needs, there is little reason for them to look elsewhere for statistical documentation - particularly when discrepancies which these alternative data might reveal are more likely to create than to solve problems of news production. Federal agencies, policing services, university researchers and other similar sources have well-articulated relationships with media agencies (Fishman, 1978) Such sources package the information for the convenient use of media agencies and it 
is through access to these channels that newsworkers meet deadlines and keep within their budgets.

Most often, articles which derived from official sources concerned trends and shifts in rates of crime, locally, provincially and nationally. To a considerable extent, these items reflect the annual, quarterly or monthly cycles according to which crime data are released by state agencies. In addition, the sample included several feature pieces which attempted to examine, in some critical fashion, trends in crime - especially violent crime - over the last two decades. Headlines such as "Criminologists say don't panic - statistics used selectively" and "Is Canada more violent? It depends on the statistics you use", appeared regularly during the 1993 federal election campaign and offered an opportunity for critical commentary on the political rhetoric of the major parties.

It is clear, however, that when state agencies do not collect statistical information in a form that speaks to the needs of primary claim-makers and journalists, others will fill the void. Thus, one item discussed how in an effort to raise consciousness about the non-official category of school violence, a provincial teachers' union had released a report which warned that the problem was "gradually increasing" and that "weapons are becoming more common and attacks more severe". The news item informed the reader that the report's conclusions "were based mostly on anecdotal evidence, recent surveys, and opinions expressed in marketresearch focus groups".

\section{Statistical Claims and the Flow of News}

Contemporary definitions of news emphasize the episodic character of specific incidents. News consists primarily of events which transpire between the publication of subsequent editions of a newspaper or subsequent news broadcasts. At the most preliminary level, it is important to ask how statistical news conforms to the periodicity of popular journalism. In short, how do statistical claims happen? Like other social problems claims, those of a statistical nature must be hung on particular kinds of news hooks (Best, 1989a).

The sample of news items suggests that statistical claims enter the news flow in three distinct ways. The first and most common is the data release. For example, Statistics Canada releases a report, the police hold a news conference, or the President of the Insurance Crime Prevention Bureau of Canada addresses the Canadian Association of Chiefs of 
Police. In such cases, it is the forum through which the information is released which provides the newsworthy event on which the press reports. Of course, not all attempts to make statistical claims by releasing a report or making a speech are equally likely to attract the attention of the media. Because Ministers of Justice, police chiefs, and the spokespersons of national statistical agencies occupy superordinate positions in a hierarchy of credibility (Becker, 1963), statistical claims which they issue have an aura of salience and legitimacy.

Within the sample of items reviewed, a second major form of news hook involved efforts at "debunking" or charges of statistical error. In this respect, a recurrent theme in the coverage was that new statistics call into question what earlier statistics have led us to believe. Such statistical controversies often took the form of pronouncements by an academic or a politician, or releases of reports describing earlier statistical sins. Sometimes, editorial writers took as a point of departure the lack of statistical integrity of information which, they argued, misinformed public policy makers. While many of the charges of statistical error were directed at the Violence against Women Survey, there were other examples. A series of articles in the Toronto papers, for instance, involved an exchange of accusations of data mismanagement between the Toronto police and Statistics Canada. At issue was the claim by the federal agency that crime rates were declining while the policing agency held that they were increasing. Other debates in the press focused on the amount of crime committed by foreign residents, on the General Social Survey which found that victimization levels did not increase between 1988 and 1993, and on the usefulness and validity of statistical records which included the race of offenders. The charge of statistical error was often evident in the negative phrasing of headlines. For instance, the headlines for items relating to the release of a major study on trends in youth crime typically expressed some variation on the theme, "Youth crime not soaring".

A third type of news hook involved the use of statistics as "background" information with respect to some more substantive theme. While some of these articles appeared to be triggered by hard news events, they were more often feature articles which provided a detailed treatment of some current issue. In some cases, the statistical information was a central and vital part of the story. In others, however, while the data was included, often in graphic form, it seemed to have little practical bearing on the issue in question. Thus, a story about the arrest of 
youths who had assaulted a skateboarder was accompanied by a boxed graph labelled "Violent crimes by youth soar", but no reference to it was made in the story.

\section{Presenting Statistical News}

The presentation of statistical claims requires that they be polished and interpreted in ways that facilitate conformity with the conventions of the medium (Orcutt and Turner, 1993). In specific terms, this means that such claims must be presented so that they are likely to be thought of by relevant audiences as interesting, important and objectively reported. Each of these strategic issues is discussed below.

\section{Statistical Claims as Entertaining News}

It has been suggested that by its nature, news about statistical matters is uninteresting to much of the readership of the typical daily newspaper. The sample of items examined for this study reveals that traditional journalistic conventions are often employed to enliven presentation.

The use of humour and irony suggests one such technique. For example, coverage of the release of data on automobile theft speaks of provincial variation in rates of thefts in terms that suggest a friendly rivalry. Reference is made to Quebec's loss of the "car theft crown" or car theft "championship". Word plays are particularly prevalent. An article about the use of prison for offenders who default on fines was headlined "The finer points of prison life" and an editorial which argued in favour of the use of citations rather than arrests to control impaired driving was headlined "Arresting statistics". Even the Violence Against Women Survey findings were not immune from the use of puns by headline writers. "Violence hits one in four women" declared one headline, while another read "Scope of violence hits home". An editorial which questioned the methodology of the study was headlined "A serious case of statistics abuse".

A second technique used to enhance the appeal of journalistic accounts of statistical news is the use of drama. While numbers may not themselves appear dramatic to the typical newspaper reader, the nature of the things being counted can be brought into the foreground in vivid ways. In this manner, news about crime statistics can borrow from more traditional narratives about criminal events. In the case of the Violence 
Against Women Survey, for instance, the drama was seen to reside not only in the kinds of events which the survey recounted but also in the data collection exercise itself. One journalist described the process this way:

When Statistics Canada interviewers called the woman of the house this spring, saying with deliberate blandness they were conducting a survey on personal safety, some women covertly wrote down a toll free telephone number. They could not talk now, the action implied, because home was the most dangerous place of all. Some first checked out the agency with the police. Others wept as questions hit close to the bone. Some called back later to talk about things that went far beyond the survey.

The drama of the presentation may also be evident in the use of graphics which accompany the story. An article on juvenile offending, for instance, included a chart which described trends in youth crime. Accompanying the chart was a stylized graphic of a knife-wielding juvenile. A report on the release of motor vehicle theft statistics was accompanied by a figure which described trends in motor vehicle crime. The figure appeared as a drawing on a car door which was being opened by a menacing character wearing sunglasses and a hat and who was carrying a crow bar.

Journalists also attempt to enhance the appeal of statistical news about crime through references which humanize what are often seen as dehumanized numbers. In this way, even items about the release of the findings of major statistical studies may be recast as "human interest stories". One way in which this is accomplished is through efforts which, as the colloquialism suggests, "put a human face on the numbers". A story about children killed by parents in murder suicides provided a detailed discussion of one such case and concluded, "Jessica (the child) and her mother make an almost distressingly perfect fit with the portrait Statistics Canada has drawn of child suicides."

\section{Statistical Claims as Important News}

News about statistical claims is framed as important news by emphasizing the unique character of the statistics themselves, as well as of the data collection procedures which produced them. In the former respect, the reporting of the release of the Violence Against Women Survey described the findings as indicative of a "national crisis" of "epidemic" proportions, and a "national shame". Several editorials in the days 
immediately following the release of the survey also spoke to the significance of the findings. However, important news is not always bad news and it is striking how many articles over the period in question spoke of crime rates in decline at both local and national levels. For example, out of 62 headlines which described a temporal trend in crime levels, only $29 \%$ unambiguously described increases. In $55 \%$ of the cases, rates were portrayed as stable or falling and in the remaining cases, the messages regarding the temporal trend were mixed or unclear. It would appear, contrary to many simple-minded interpretations of media treatment of crime, that news about falling crime rates was likely to receive extensive attention.

The reporting of statistical claims is also justified through an emphasis on the unique character of the study methods which produce the findings. The Violence Against Women Survey, for instance, was often described as "groundbreaking" "the most comprehensive survey ever undertaken", with the "potential to shake up society". A study of youth crime levels was also described as "groundbreaking", a Statistics Canada study of murder was "the first of its kind" and a study of sentencing was "the most comprehensive ever done".

\section{Statistical Claims as Objectively Reported News}

Statistical claims, like all forms of news, must be presented in ways that allow for the demonstration of journalistic objectivity. The achievement of this goal is complicated by the fact that such claims often appear as government pronouncements, the precise character of which journalists may be ill-prepared to assess. Several strategies are available to journalists for the resolution of this problem.

First, news reporting on crime and victimization statistics often appears to promote a self-critical style which encourages news consumers to be cautious about what the media tell them about statistical matters. Over the study period, there was considerable evidence of press attention to critics who blamed the media for misrepresenting crime levels and trends. These critics were often academics (although even the Federal Justice Minister was cited as blaming the media for the discrepancies between perceptions of crime and "objective" realities). Typically, in such reporting, it was charged that the media disproportionately emphasized rising crime rates, and that they were insufficiently attentive to the vagaries of most forms of crime measurement. As one headline read, "It is criminal how the media report crime in this country, 
according to a University of Winnipeg criminologist". Such a level of attention to self-critique invites a judgment of journalistic balance. However, as suggested above, the irony here is that there is considerable evidence to suggest that the press is no less attentive to news about low and declining crime rates than to news about rising rates.

The objective character of reporting is also made explicit through critical coverage of the relationship between party politics and statistical rhetoric about crime and victimization. Thus, while government agencies are the usual source of statistical claims, a critical attitude to government helps to create the impression of professional distance and of a lack of journalistic bias. In the content examined, such coverage was, overall, more generally adversarial than it was methodologically consistent. The federal government, for instance, was criticized by columnists and editorial writers for exaggerating crime levels (in the case of violence against women) and minimizing the seriousness of the crime problem (in the case of young offenders of crimes by immigrants). As stated, the study period included federal election coverage. Since all major parties attempted to stake out positions on crime control, coverage of the election required coverage of how crime trends and crime levels were differently interpreted by politicians. A feature piece, headlined "The Politics of Fear", stated, "It's campaign time and people are scared: that's fertile ground for stretching the crime stats way out of shape." A recurrent theme voiced by the small group of academics whom the press routinely consult for comment when findings are released, is that those who have political power or those who seek it will use statistics about crime for political advantage. Thus, one academic criminologist warned that politicians have duped Canadians into thinking crime has reached epidemic proportions so they can get more money for their budgets. According to another, political leaders pretty well ignore the data because the political payoff comes from talking tough on law and order.

Although the sample of items used in this analysis included several feature pieces which focused on the unreliability of police and survey measures of crime, this does not negate the way in which the inherent character of statistical claims and the official nature of their sources support the appearance of objectivity. There is a sense in which numbers are understood as more factual, more impartial and more precise than mere words. The claim that one in 10 automobiles is the object of a theft does not appear to be equivocal or interest-driven. Moreover, the "official" source of much statistical claim-making lends legitimacy 
and impartiality to such claims, but this is not always non-problematic. While spokespersons for federal agencies consistently try to portray these agencies as disinterested social observers, the connection between statistics about victimization and victim policy often makes such organizational self-presentation exceptionally difficult. The most obvious but not the only - instance of this problem involved the Violence Against Women Survey. Almost exactly one year after the release of the survey, and prompted to some extent by the writings of an academic critic (Fekete, 1994), a number of columnists called the impartiality of Statistics Canada into question. One columnist attempted to explain why the StasCan tale (of pervasive violence against women) needs "debunking" while another claimed to have heard, informally, that the survey had been under the control of a group of "diehard feminists".

More generally, the dominant strategy for meeting objectivity requirements is that of presenting the opinions of experts and other interested parties who are thought to bring a range of interests and interpretations to the statistical claims in question (Welch et al., 1998). In addition to study authors or agency spokespersons, there appear to be three such groups to whom journalists seem to have easy access and from whom they solicit contextualizing comments.

The first such group, academic criminologists, typically encourages caution in the interpretation of data. They warn that rates frequently reflect various types of bias and that little can be learned from research which attempts to compare data across a small number of reporting periods. Often they are explicitly critical of the statistical claims made by police and (especially conservative) politicians.

For the second group, the police, commentary routinely reflects organizational interests. While police spokespersons have sometimes straightforwardly taken credit for falling crime rates, they more frequently have endeavored to explain why particular statistical claims meant something other than what academics or political advocates suggested they meant. Often they have charged that indicators of falling or stable rates of crime were deceptive and that crime problems were more serious than the numbers would lead anyone to believe. Frequently, the attitude towards statistical information has been dismissive. In attempting to explain how Toronto's crime rates could be worsening when Statistics Canada suggested otherwise, the Toronto Chief of Police was quoted as saying "I am not quarreling with the statistical data but reality is a different story." 
The third group, victim advocates, often expressed views about crime statistics which were consistent with those espoused by the police. Thus, for this group, statistics were more believable when they described problems as worsening. Understandably, the rhetoric of academics on the one hand, and of the police and victim advocates on the other, was often in conflict and it is in the character of this conflict that journalistic objectivity resides. The interpretive variation implicit in the quotes provided by police, victim advocates and academics encourages a view that coverage is fair and balanced.

\section{Conclusion}

How and why do journalists make use of statistical claims about crime and victimization? One answer to this question stresses the routine ways in which journalists employ numbers to lend credibility and legitimacy to stories. Thus, while the explicit objective of the journalist is to "report" rather than to "persuade", the intention is always to offer a convincing construction of reality (Orcutt and Turner, 1993). Statistical rhetoric legitimates journalistic interest and invites public attention. However, it has been argued that journalists use numbers sparingly because they fear that their audiences will find them boring. This analysis casts at least some doubt on that assertion. During the period under study there was a considerable amount of reporting of statistical claims regarding crime and victimization. Moreover, while such coverage might be assessed by the readership as less interesting than other kinds of stories - especially other kinds of crime stories - there was evidence of a substantial effort to dress items that involved statistics in ways that emphasized humour, drama and public interest.

A persistent theme in media criticism reporting of crime and in much constructionist sociology is that there exists a strong media preference for bad news, and that attempts on the part of academic or government researchers to provide evidence of moderating trends in crime are undermined by journalistic sensationalism which distorts the statistical picture (Krajicek, 1998). Thus, just as a small number of criminal incidents can, after journalistic treatment, appear to an audience as a crime wave, statistical trends which might suggest otherwise can, after journalistic treatment, appear to provide incontrovertible evidence of a problem out of control (Orcutt and Turner, 1993). The analysis presented here, however, suggests that such an argument is too simplistic. 
There were, for example, numerous examples of "good news" in the form of headlines and reporting regarding stable or declining crime rates. There were also several cases of critical scrutiny by the press of exaggerated statistical estimates of the crime problem and even of the role played by the media in the diffusion of such estimates. However, for several reasons, such findings are not inconsistent with contemporary theoretical insights regarding the role played by mass media in the construction of crime and victimization problems.

First, and perhaps most cynically, it can be argued that it is not always in the interest of claim-makers to promote an image of crime as pervasive and increasing. Political and bureaucratic interests may well seek to promote a view of crime as under effective control, and thus of those in control as effective and efficient. It is partly for this reason that official agencies eagerly seize the opportunity to produce crime and other social problem statistics.

As well, state bureaucracies concerned with data collection and dissemination pursue agendas of their own. Altheide and Johnson (1980) note that such organizations need to convince audiences of their relevance. The generation of data which, it can be claimed, documents levels of crime, homelessness, poverty and other social problems, is a highly visible and readily apparent way through which this is accomplished. In this sense, social problem statistics reveal something not only about the problem in question, but also about the agency which produces the statistics. It is in this respect that numbers can be understood as "bureaucratic propaganda".

But the mix of good, bad and inconsistent news concerning crime probably reveals a more complex dynamic. As stated, the organizational character of the news production process, and the sheer numbers of journalists, encourages reliance on statistical information from credible sources. Thus, in the case of both emergent and established problems, news stories are often organized around the release of statistical estimates in the form of a "new study" or the regular releases of social problem indicators such as the Uniform Crime Reports. As with other forms of crime news, such statistical reports are prepared in ways that are intended to maximize media attention (Best, 1988). Thus, a report of several hundred pages will be condensed into a brief press release which is likely to emphasize a limited number of key findings. A review of several of Statistics Canada press releases, however, suggests that newsworkers do not, in general, stray very far from the content of these 
releases. The trends, themes and major findings which those who generate statistical claims emphasize tend, on the whole, to be the same ones which are emphasized in the press coverage. To some degree, therefore, charges of media sensationalism are misplaced. When big shocking numbers were emphasized in press reports, it is likely that they were emphasized as well in the press releases to which the coverage is a response. Again, the character of the news production process makes any other outcome unlikely. However, even in the case of reports of high or increasing rates of victimization, reliance by journalists on liberal social scientists to provide a context for such numbers is as likely to result in equivocation as in a consistent and clear message that crime is rampant.

Moreover, the dynamics which characterize the relationship between the early and often extravagant claims of problem advocates, and the later claims which emerge from state-sponsored data collection enterprises, are often marked by tension. Those who propose new problem definitions typically do so with few resources and are not well placed to demonstrate the statistical accuracy of their views (Gillesp and Leffler, 1987). The data collected by state agencies, however, is more likely to follow the accepted methodological conventions of social science and to reflect a greater investment of financial and human resources. Moreover, the legitimacy of state statistical agencies rests, to a considerable degree, on the shared public perception that they are acting less like problem advocates and more like social accountants. Not surprisingly, the statistical claims of state agencies often contradict early problem estimates. Cook and Skogan (1990), for instance, have shown how initial attempts by advocates to construct the problem of crimes against the elderly, through the use of claims that the elderly suffered the highest rates of victimization of any group in society, were undercut by wave after wave of National Crime Survey results which suggested quite unequivocally that the elderly were the least, not the most, victimized group in society.

It is also sometimes the case that statistical releases regarding either emergent or established problems provide controversies, creating opportunities for two kinds of stories. While the original coverage may focus on the release of statistical estimates, subsequent coverage may focus on "debunking" these estimates (Gilbert, 1994). Best (1988) showed how the Denver Post and other papers attacked the high estimates of missing children offered by earlier claim-makers. More relevant to the present study, Doob (1995) has described the ways in which Canadian media called into 
question the findings of the 1993 Violence Against Women Survey by attacking the motives of the researchers and the character of the study.

In general, Gillesp and Leffler (1987) maintain that research which proposes a new problem definition will receive more critical scrutiny than research which is supportive of established views. Statistics which are claimed to describe social problem conditions, and the methodologies which produce them, are most likely to lead to debate when the problem under construction threatens or challenges existing interests. Claims regarding particular forms of victimization, such as sexual harassment or hate crime, for example, may imply new legal entitlements or legislative changes which are likely to invite considerable opposition. To some extent, this opposition will focus on the statistical grounds from which the problem definition arises.

How press (or broadcast) reports of statistical claims are attended to or interpreted by audience members is an issue that extends well beyond the scope of this research. Certainly, the net effect of such coverage is difficult to estimate. While coverage of statistical claims about crime and victimization is extensive and often critical, and while much of this news concerns falling crime rates, what remains unclear is the differential significance which audience members attach to several stories about falling murder rates versus a single sensationalist story about a particular murder. In addition, overall, the statistical picture of crime which emerges in the print media examined in this study is inconsistent and confusing. Even though the range of statistical sources is rather truncated and skewed in the official direction, there is evidence that some rates are going up while others are falling and still others are remaining stable. Moreover, the contextual commentary which journalists seek from academics, politicians, and police spokespersons is often of the kind that will call into question whatever statistical claims are being pressed. In this respect, at least, numbers never speak for themselves.

\section{References}

ALtheide, D.L. and JoHnSON, J.M. 1980. Bureaucratic propaganda, Boston: Allyn and Bacon.

BECKER, H. 1963. Outsiders: Studies in the sociology of deviance, New York: The Free Press.

BEST, J. 1988. "Missing children, misleading statistics", The Public Interest 92 (summer): 84-92. 
BEST, J. 1989a. "Secondary claims-making: claims about threats to children on the network news", p. 259-282 in Perspectives on Social Problems: A Research Annual, J.A. Holstein and G. Miller (eds.). Greenwich Conn.: JAI Press.

BEST, J. 1989b. "Dark figures and child victims: Statistical claims about missing children", p. 21-37 in Images of Issues, J. Best (eds.). New York: Aldine de Gruyter.

BEST, J. 1999. Random violence: How we talk about new crime and new victims, Berkeley: The University of California Press.

ChIBNALL, S. 1977. Law and order news: An analysis of crime reporting in the British press, London: Tavistock.

COOK, F.L. and SKOGAN, W.G. 1990. "Agenda setting and the rise of policy issues: the case of criminal victimization of the elderly" Environment and Planning C: Government and Policy, 18: 395-415.

DooB, A.N. 1995. "Understanding the attacks on Statistics Canada's violence against women survey" p. 157-165 in Wife Assault and the Canadian Criminal Justice System M. Valverde, L. MacLeod and K. Johnson (eds.). Toronto: Centre of Criminology, University of Toronto.

Ericson, R.V., BaraneK, P.M. and Chan, J.B.L. 1989. Negotiating control: A study of news sources, Toronto: University of Toronto Press.

ERICSON, R.V., BARANEK, P.M. and CHAN, J.B.L. 1991. Representing order: crime, law and justice in the news media, Toronto: University of Toronto Press.

FeKeTE, J. 1994. Moral panic, Montreal: Robert Davies Publishing.

Fishman, M. 1978. “Crime waves as Ideology”, Social Problems 25: 531-543.

Gans, H. 1979. Deciding what is news, New York: Pantheon.

Gilbert, N. 1994. "Miscounting social ills", Society 31 (3): 18-26.

Gilbert, N. 1997. "Advocacy research and social policy" Crime and justice: $A$ review of research: 101-148.

GILLESPIE, D.L. and LEFLER, A. 1987. "The politics of research methodology in claims-making activities: social science and sexual harassment", Social problems 34 (5): 490-501.

GoOde, E. and Ben-YeHudA, N. 1994. Moral panics: The social construction of deviance, Oxford: Blackwell Publishers.

HowitT, D. 1982. The mass media and social problems, Oxford: Pargamon Press.

JENKINS, P. 1994. Using murder, New York: Aldine de Gruyter.

KRAJICEK, D.J. 1998. Scooped! Media miss real story on crime while chasing sex, sleaze and celebrities, New York: Columbia University Press.

Nelson, B.J. 1984. Making an issue of child abuse, Chicago: University of Chicago Press.

ORCUTT, J.D. and TURNER, J.B. 1993. "Shocking numbers and graphic accounts: Quantified images of drug problems in the print media", Social problems 40 (2): 190-206.

Welch, M., Fenwick, M. and Roberts, M. 1998. "A content analysis of ideology in experts quotes in feature newspaper articles on crime", p. 87110 in Constructing Crime, G.W. Potter and V.E. Kappeler (eds.). Prospect Heights Ill: Waveland Press. 